\title{
Pelatihan Keterampilan Government Public Relations Melalui Media Management Tools Dalam Membangun Peradilan Kredibel di Lingkungan Mahkamah Agung
}

\author{
Andre Ikhsano ${ }^{1}$, Yolanda Stellarosa ${ }^{2}$ \\ 1,2Program Studi IImu Komunikasi, Institut Komunikasi dan Bisnis LSPR, Jakarta, Indonesia
}

\begin{abstract}
ABSTRAK
Pemahaman berkomunikasi, khususnya bagi tim public relations atau kehumasan di pemerintah sangat diperlukan. Terlebih telah diamanahi melalui Inpres No. 9 tahun 2015. Berbagai macam tantangan yang tinggi akibat adanya pandemic covid 19, Undang-undang Keterbukaan Informasi Publik, massifnya media digital; mengakibatkan masyarakat lebih kritis dan lebih peduli akan haknya, baik hak politik, hak ekonomi, hak sosial, hak budaya sampai pada hak hukum, kecepatan proses hukum, pelayanan hukum dan transparansi serta akuntabilitas produk hukum. Untuk itu, dibutuhkan pemahaman kehumasan dan keterampilan melakukan hubungan dengan media (media management) yang baik. Hal tersebut diperlukan untuk mendistribusikan data dan informasi sehingga dapat membantu narasi tunggal pemerintah, khususnya membantu menciptakan peradilan yang kredibel. Pengabdian kepada masyarakat ini dilakukan dalam bentuk penyuluhan kepada para ketua pengadilan, hakim dan tim hubungan masyarakat di lingkungan Mahkamah Agung. Kegiatan yang dilakukan secara virtual ini memberikan hasil yang bagus dan dapat dilanjutkan di kemudian hari dengan peserta yang berbeda atau dengan peserta yang sama namun dengan materi-materi lainnya seperti community relations, public speaking, agenda setting guna mendukung pemahaman dan keterampilan yang sudah didapatkan.
\end{abstract}

Kata kunci: Public Relations; Manajemen Media; Peradilan Kredibel

\begin{abstract}
Understanding of communication, especially for the public relations team in government, is needed. Moreover, it has been entrusted with Inpres No. 9 of 2015. Various kinds of high challenges due to the COVID-19 pandemic, the Public Information Openness Act, the massive digital media; resulting in society being more critical and more concerned about their rights, both political rights, economic rights, social rights, cultural rights to legal rights, speed of legal processes, services and transparency and accountability of legal products. For that, an understanding of public relations and good media management skills is needed. This is necessary to distribute data and information so that it can help the government's single narrative, in particular, help create a credible judiciary. This community service is carried out in the form of counseling to court heads, judges, and public relations teams within the Supreme Court. The activities carried out virtually give good results and can be continued at a later date with different participants or with the same participants but with other materials such as community relations, public speaking, agenda settings to support the understanding and skills acquired.
\end{abstract}

Keywords: Public Relations; Media Management; Credible Judiciary 


\section{PENDAHULUAN}

Keterampilan berkomunikasi, khususnya dalam bidang public relations saat ini menjadi sangat signifikan, terutama sejak digaungkannya revolusi industri 4.0 di Indonesia. Perubahan tidak hanya terjadi pada sektor swasta tetapi juga di pemerintahan. Semua lembaga dan institusi, baik swasta maupun pemerintah sangat membutuhkan keterampilan public relations dalam menjalin berbagai macam komunikasi kepada masyarakat. Selain itu tentunya untuk terus mengembangkan berbagai inovasi dan kreativitas dalam membangun kepercayaan dan reputasi institusi.

Pemerintah dalam beberapa tahun ini sangat memberikan perhatian terhadap Goverment Public Relations (GPR). Pengelolaan komunikasi publik pemerintah melalui Government Public Relations tertuang dalam Inpres No 9 tahun 2015 (Kementerian Komunikasi dan Informatika RI, 2016). Fungsi utama dari government public relations antara lain menekankan pada: 1) penyusunan narasi tunggal, 2). merencanakan, menyiapkan dan mengkoordinasikan agenda setting pemerintah dan 3) pemerintah menyampaikan informasi, kebijakan dan program melalui berbagai macam saluran komunikasi secara cepat dan tepat untuk mengimbangi arus pemberitaan di media massa (Iprahumas Indonesia, 2020). Hal ini sesuai pula dengan penelitian yang dilakukan oleh Widowati (2019) yang menyatakan bahwa public relations sangat penting untuk menjalin hubungan baik dengan para stakeholder, diantaranya dengan media dalam menyampaikan informasi.

Dari tiga fungsi utama government public relations tersebut, maka dapat terlihat adanya upaya pemerintah untuk dapat mengimbangi arus informasi yang beredar di masyarakat. Dengan berbagai perkembangan media, khususnya media digital yang sangat massif; mengakibatkan terbukanya keran informasi dan data. Dalam hal ini data dan informasi bertebaran dengan cepat dan massif. Sebagian dari data dan informasi tersebut tentu tidak terlepas dari pemberitaan-pemberitaan yang bernada negatif, menyudutkan atau justru berisi berita bohong mengenai pemerintah dan berbagai macam kebijakannya. Hal ini tentunya berhubungan dengan reputasi dan citra pemerintah di tengah era yang serba digital ini. Tidak dapat dipungkiri bahwa konten dan media menjadi fokus utama untuk menciptakan reputasi dan citra baik dari pemerintah.

Mahkamah Agung sebagai bagian dari pemerintah mempunyai perhatian dalam pengembangan keterampilan berkomunikasi, khususnya terkait hubungan dengan media. Tantangan banjirnya informasi, munculnya undang-undang Keterbukaan Informasi Publik (KIP) No. 14 tahun 2008 yang menuntut semua institusi atau lembaga pemerintah bertindak transparans. Perkembangan Information Communication Technology (ICT) dan mulai merebaknya Internet of Things (IOT) membuat tatanan berkomunikasi dan berbudaya berubah. Berbagai macam tantangan di atas ini coba dijawab oleh Mahkamah Agung melalui berbagai macam pelatihan di bidang keterampilan berkomunikasi dan keterampilan 
kehumasan. Seperti diungkapkan oleh Breakendriedge (2008) bahwa PR.2.0 hadir melalui analisis bagaimana web dan multimedia mendefinisikan ulang kegiatan hubungan masyarakat dan komunikasi pemasaran; sementara juga membangun perangkat untuk menentukan kembali bagaimana perusahaan berhubungan tidak hanya dengan jurnalis konvensional tetapi juga dengan para influencer yang saat ini marak meramaikan media digital serta kemampuan dari seorang public relations untuk berkomunikasi dengan audiensnya melalui berbagai forum online, komunitas dan sebagainya.

Institut Komunikasi dan Bisnis LSPR yang memiliki keunggulan dalam bidang komunkasi dan public relations bekerjasama dengan Mahkamah Agung melalui Pusdiklat Mahkamah Agung untuk memberikan pelatihan dan sertifikasi di bidang public relations kepada pada ketua pengadilan, hakim, serta tim hubungan masyarakat di lingkungan Mahkamah Agung.

Kegiatan pengabdian kepada masyarakat berupa penyuluhan ini bertujuan untuk memberikan pemahaman dan keterampilan kepada semua ketua pengadilan, hakim dan tim hubungan masyarat akan pentingnya keterampilan public relations atau kehumasan khususnya dalam berhubungan dengan media. Tujuan yang ingin dicapai adalah agar para ketua pengadilan, hakim dan personil hubungan masyarakat (humas) dapat mengapilkasikannnya dalam aktivitas sehari-hari dan mampu ikut membantu menciptakan sistem peradilan yang kredibel.

\section{METODE PELAKSANAAN}

Metode yang digunakan dalam kegiatan pengabdian kepada masyarakat ini berbentuk pelatihan atau penyuluhan mengenai keterampilan public relations, khususnya berhubungan dengan media. Kegiatan pengabdian kepada masyarakat ini dimulai dari tanggal 05-09 Oktober 2020 dengan berbagai macam narasumber atau penyuluh. Pada hari pertama, kegiatan dibagi menjadi dua sesi, sesi pertama dimulai dari jam 09.30-11.30 WIB berupa pemaparan dari berbagai narasumber yaitu: Prita Kemal Gani MBA, MCIPR, APR selaku Founder \& CEO dari Institut Komunikasi dan Bisnis LSPR yang juga sebagai President APRN (ASEAN Public Relations) memberikan topik public relations: persuasion, personality dan power; lalu dilanjutkan dengan pembicara kedua; Bpk. Johan Budi selaku anggota DPR-RI yang juga sangat berpengalaman sebagai praktisi Public relations ketika di Komisi Pemberantasan Korupsi (KPK), lalu pembicara ketiga adalah Prof. Dr. Hikmahanto Juwono yang memberikan topik mengenai sistem hukum dan peradilan yang humanis.

Sesi kedua pada pengabdian kepada masyarakat dilakukan pada jam 13.00-16.00 WIB dengan pembicara pertama Ibu Ani Natalia selalu Humas Ditjen pajak yang memaparkan pengalaman mengelola kehumasan di Direktorat Jendral Pajak; lalu pembicara kedua adalah Dr. Andre Ikhsano, M.Si yang memaparkan dan memberikan penyuluhan mengenai keterampilan 
government relations; media management tools dalam menciptakan peradilan yang kredibel. Pembicara terakhir di sesi kedua ditutup dengan pak Jamalul Insan dari Dewan Pers yang memaparkan bagaimana berkomunikasi dengan media, apa saja nilai berita yang diharapkan dari sisi media atau pers. Pada penulisan ini, difokuskan pada pelatihan keterampilan public relations yang dipaparkan oleh Dr. Andre Ikhsano, M.Si yang menekankan pentingnya keterampilan media management tools.

Kegiatan pengabdian ini dilakukan secara virtual melalui aplikasi zoom karena masih dalam kondisi di tengah pandemi Covid 19. Walaupun dilakukan secara virtual, kegiatan pelatihan ini tetap mengedepankan berbagai macam aspek keterampilan berupa studi kasus dan lain sebagainya yang dilakukan sejak hari pertama sampai dengan hari terakhir. Untuk membuat lebih efektif, maka pada pelatihan ini dibentuk menjadi kelompok kecil dimana setiap kelompoknya terdiri dari maksimal 10 peserta. Rincian pelaksanaan dan juga penjelasan mengenai mekanisme pelatihannya adalah sebagai berikut:

Tabel 1: Rincian Pelaksanaan Penyuluhan Government Public Relations; Media Management Tools

\begin{tabular}{|c|c|c|c|c|}
\hline No & & Kegiatan & PIC & Waktu \\
\hline 1 & Pers & pan & $\begin{array}{l}\text { Lembaga Sertifikasi Profesi } \\
\text { LSPR dan Mahkamah Agung }\end{array}$ & \\
\hline & 1.1. & $\begin{array}{l}\text { Koordinasi LSP-LSPR dengan } \\
\text { Mahkamah Agung }\end{array}$ & $\begin{array}{l}\text { Lembaga Sertifikasi Profesi } \\
\text { LSPR dan Mahkamah Agung }\end{array}$ & $\begin{array}{l}21 \\
\text { September } \\
2020\end{array}$ \\
\hline & 1.2 . & Pembagian kerja & $\begin{array}{l}\text { Lembaga Sertifikasi Profesi } \\
\text { LSPR }\end{array}$ & $\begin{array}{l}22 \\
\text { September } \\
2020\end{array}$ \\
\hline & 1.3. & $\begin{array}{l}\text { Koordinasi panitia } \\
\text { pelaksana Pelatihan }\end{array}$ & Ketua LSP-LSPR & $\begin{array}{l}22 \\
\text { September } \\
2020\end{array}$ \\
\hline & 1.4 . & $\begin{array}{l}\text { Penunjukan pemberi materi } \\
\text { pelatihan }\end{array}$ & $\begin{array}{l}\text { Ketua LSP-LSPR dan Dewan } \\
\text { Pembina LSP-LSPR }\end{array}$ & $\begin{array}{l}23 \\
\text { september } \\
2020\end{array}$ \\
\hline & 1.5 & $\begin{array}{ll}\text { Pembuatan } & \text { materi } \\
\text { pelatihan } & \end{array}$ & Masing-masing Pembicara & $\begin{array}{l}23-28 \\
\text { September } \\
2020\end{array}$ \\
\hline & 1.6 & $\begin{array}{ll}\text { Penunjukan peserta } \\
\text { pelatihan }\end{array}$ & Mahkamah Agung & $\begin{array}{l}25 \\
\text { September } \\
2020\end{array}$ \\
\hline & 1.7 & Evaluasi materi & $\begin{array}{l}\text { Ketua LS-LSPRP dan Dewan } \\
\text { Pembina LSP }\end{array}$ & $\begin{array}{l}30 \\
\text { September } \\
2020\end{array}$ \\
\hline
\end{tabular}




\begin{tabular}{|c|c|c|c|c|}
\hline & 1.8 & Sosialisasi acara penyuluhan & Mahkamah Agung & $\begin{array}{l}28-30 \\
\text { September } \\
2020\end{array}$ \\
\hline & 1.9 & $\begin{array}{l}\text { Pembuatan Budget } \\
\text { Pelatihan/penyuluhan }\end{array}$ & Panita, seksi biaya & $\begin{array}{l}25 \\
\text { September } \\
2020\end{array}$ \\
\hline & 1.10 & $\begin{array}{l}\text { Briefing } \\
\text { pembicara/penyuluh }\end{array}$ & Ketua LSP-LSPR & $\begin{array}{l}1 \text { Oktober } \\
2020\end{array}$ \\
\hline & 1.11 & $\begin{array}{l}\text { Persiapan teknis; aplikasi } \\
\text { zoom, latar belakang zoom, } \\
\text { tata tertib acara, dan lain- } \\
\text { lain }\end{array}$ & Panitia Pelatihan & $\begin{array}{l}\text { 1-2 Oktober } \\
2020\end{array}$ \\
\hline & 1.12 & $\begin{array}{l}\text { Evaluasi; checklist persiapan } \\
\text { acara }\end{array}$ & Panitia Pelatihan & $\begin{array}{l}3 \text { Oktober } \\
2020\end{array}$ \\
\hline \multirow[t]{4}{*}{2} & \multicolumn{2}{|c|}{ Pelaksanaan Penyuluhan/Pelatihan } & & $\begin{array}{l}\text { 5-9 Oktober } \\
2020\end{array}$ \\
\hline & 2.1 & $\begin{array}{l}\text { Pengecekan kesiapan } \\
\text { pembicara; panitia; host, hal } \\
\text { teknis }\end{array}$ & Panitia; seksi acara & $\begin{array}{l}\text { 5-9 Oktober } \\
2020\end{array}$ \\
\hline & 2.2 & $\begin{array}{ll}\text { Pengecekan Kehadiran } \\
\text { peserta }\end{array}$ & Panitia; seksi acara & $\begin{array}{l}\text { 5-9 Oktober } \\
2020\end{array}$ \\
\hline & 2.3 & Penyuluhan Public Relations & Pembicara/penyuluh & $\begin{array}{l}\text { 5-9 Oktober } \\
2020\end{array}$ \\
\hline \multirow[t]{5}{*}{3} & \multicolumn{2}{|c|}{ Pasca pelaksanaan } & & \\
\hline & 3.1 & $\begin{array}{l}\text { Penghargaan pada } \\
\text { pembicara/penyuluh }\end{array}$ & $\begin{array}{l}\text { Lembaga Sertifikasi Profesi } \\
\text { LSPR }\end{array}$ & $\begin{array}{l}\text { 5-9 Oktober } \\
2020\end{array}$ \\
\hline & 3.2 & Penerbitan e-sertifikat & Panitia; seksi acara & $\begin{array}{l}\text { 5-9 Oktober } \\
2020\end{array}$ \\
\hline & 3.3. & $\begin{array}{l}\text { Evaluasi } \\
\text { pelatihan/penyuluhan }\end{array}$ & Panitia & $\begin{array}{l}12 \text { Oktober } \\
2020\end{array}$ \\
\hline & 3.3 & $\begin{array}{ll}\text { Laporan } & \text { kegiatan } \\
\text { Penyuluhan } & \\
\end{array}$ & Panitia & $\begin{array}{l}15 \text { Oktober } \\
2020\end{array}$ \\
\hline
\end{tabular}

Adapaun sususan acara pada pelatihan/penyuluhan keterampilan government pubic relations; Media management tools ini sebagai berikut:

Tabel 2: Susunan Acara Pelatihan/Penyuluhan Keterampilan Government PR; Media Management Tools di Lingkungan Mahkamah Agung Tanggal 05 Oktober 2020

\begin{tabular}{|c|c|c|l|c|}
\hline Tanggal & Waktu & Durasi & Kegiatan & PIC \\
\hline & 08.45-09.00 & 15 menit & Registrasi online & Seksi Acara \\
\hline
\end{tabular}




\begin{tabular}{|c|c|c|c|c|}
\hline \multirow{16}{*}{$\begin{array}{l}5 \\
\text { Oktober } \\
2020\end{array}$} & 09.00-09.05 & 5 menit & MC membuka acara & MC \\
\hline & $09.05-09.10$ & 5 menit & Menyanyikan Indonesia Raya & Tapping \\
\hline & $09.10-09.20$ & 10 menit & $\begin{array}{l}\text { Pembukaan oleh Kepala Badan } \\
\text { Litbang Diklat Kumdil Mahmakah } \\
\text { Agung }\end{array}$ & $\begin{array}{l}\text { Dr. Zarof } \\
\text { Ricar, S.H., } \\
\text { S.Sos., } \\
\text { M.Hum. }\end{array}$ \\
\hline & $09.20-09.30$ & 10 menit & Sambutan oleh Direktur LSP-LSPR & $\begin{array}{l}\text { Deddy } \\
\text { Irwandy } \\
\text { M.Si }\end{array}$ \\
\hline & \multicolumn{4}{|c|}{ Sesil } \\
\hline & $09.30-10.15$ & 45 menit & $\begin{array}{l}\text { Materi 1: PR: Persuasion, } \\
\text { Personality \& Power }\end{array}$ & $\begin{array}{l}\text { Prita Kemal } \\
\text { Gani, MBA } \\
\text { dan Host }\end{array}$ \\
\hline & $10.15-11.00$ & 45 menit & $\begin{array}{l}\text { Materi 2: Government Public } \\
\text { Relations }\end{array}$ & Johan Budi \\
\hline & $11.00-11.45$ & 45 menit & $\begin{array}{l}\text { Materi 3: sistem hukum dan } \\
\text { peradilan yang humanis. }\end{array}$ & $\begin{array}{l}\text { Prof. Dr. } \\
\text { Hikmahanto } \\
\text { Juwono }\end{array}$ \\
\hline & $11.45-13.00$ & 45 menit & Ishoma & \\
\hline & \multicolumn{4}{|c|}{ Sesi 2} \\
\hline & $13.00-13.35$ & 45 menit & $\begin{array}{l}\text { Materi 1: Best Practice } \\
\text { Government PR }\end{array}$ & $\begin{array}{l}\text { Ani Natalia- } \\
\text { Direktorat } \\
\text { jendral } \\
\text { Pajak RI }\end{array}$ \\
\hline & $13.35-14.30$ & 45 menit & $\begin{array}{l}\text { Materi 2: Keterampilan } \\
\text { Government Relations; Media } \\
\text { management Tools }\end{array}$ & $\begin{array}{l}\text { Dr. Andre } \\
\text { Ikhsano- } \\
\text { Rektor IKB } \\
\text { LSPR }\end{array}$ \\
\hline & $14.30-15.15$ & 45 menit & $\begin{array}{l}\text { Materi 3: Media relations; News } \\
\text { Values }\end{array}$ & $\begin{array}{l}\text { Bpk. } \\
\text { Jamalul } \\
\text { Insan- } \\
\text { Dewan Pers }\end{array}$ \\
\hline & $15.15-15.30$ & 15 menit & QA & Host \\
\hline & $15.30-15.45$ & 15 menit & Informasi oleh panitia & \\
\hline & 15.45 & & Penutupan & \\
\hline
\end{tabular}




\section{HASIL DAN DISKUSI}

Institut Komunikasi dan Bisnis LSPR melalui Lembaga Sertifikasi Profesi LSPR pada tanggal 0509 Oktober 2020 memberikan pelatihan secara virtual kepada 100 peserta yang terdiri dari ketua pengadilan, hakim, dan personil humas di lingkungan Mahkamah Agung secara nasional. Acara pelatihan atau penyuluhan pada tanggal 05 Oktober 2020 dmulai pada jam 08.45 dengan registrasi, lalu dibuka oleh MC (Master of Ceremony) dan dilanjutkan dengan menyanyikan lagu Indonesia raya, selanjutnya adalah sambutan-sambutan, pada sesi pertama berlangsung dari jam 09.30 sampai 11.45 WIB, sedangkan sesi ke dua dimulai dari jam 13.00 sampai jam 15.30 WIB.

Pada sesi kedua, penyuluhan dilakukan oleh 3 (tiga) narasumber, salah satunya oleh Dr. Andre Ikhsano, M.Si. Dimulai dengan memberikan pretest melalui pengisian di google form mengenai pengetahun dan keterampilan dasar public relations, khususnya manajemen media. Hasil pretest mengindikasikan bahwa sebagian besar peserta belum begitu memahami Public Relations, terlebih mengenai manajemen media. Selanjutnya penyuluh memaparkan mengenai latar belakang kondisi saat ini yang dihadapi, baik itu aspek tantangan dan kesempatan (challenges and opportunity) seperti yang tergambarkan di slide penyuluhan yang diungkapkan oleh pembicara yang tergambarkan pada gambar 1.

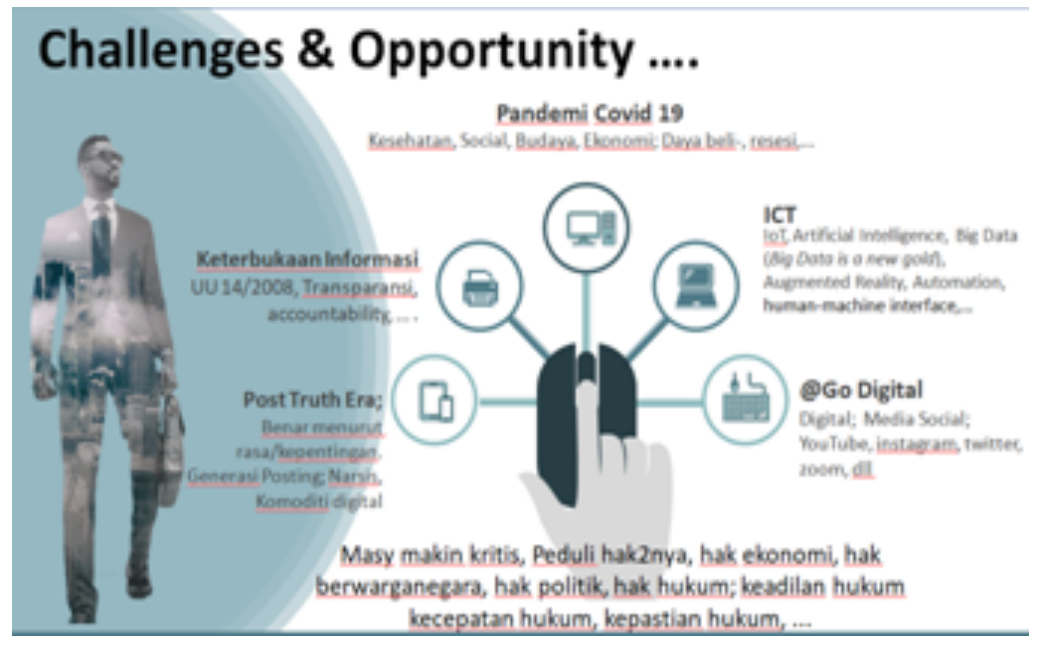

Gambar 1: Tantangan dan Kesempatan

Kondisi pandemi yang kita hadapi saat ini berdampak pada semua sektor, baik itu kesehatan, sosial, ekonomi, politik dan sektor lainnya. Resesi ekonomi yang dihadapi Indonesia menjadi pukulan besar dan tantangan yang dihadapai dalam beberapa bulan mendatang. Keterbukaan Informasi melalui Undang-undang Keterbukaan Informasi Publik nomor 14 tahun 2008 yang menuntut semua lembaga pemerintah untuk transparan dan akuntabel.

Pada era post truth yang mengedepankan kebenaran menurut rasa, tidak lagi berdasarkan kebenaran yang sesungguhnya. Serta terkait dengan perkembangan dunia digital yang sangat 
massif, penetrasi pengguna internet di Indonesia yang mencapai 64\%, atau 175 juta dari 272 juta jiwa penduduk Indonesia, konsumsi internet masyarakat Indonesia yang mencapai 8 jam sehari, apalagi di masa pandemi sekarang ini. 80\% konsumsi internet di Indonesia adalah media sosial, sedangkan aplikasi whatapps dikonsumsi sekitar 143 juta penduduk Indonesia, pengguna facebook di Indonesia menempati urutan ke tiga dunia, setelah India dan Amerika, sedangkan konsumsi Intagram masyarakat Indonesia berada di urutan ke 4 dunia dan twitter berada di urutan depalan dunia (we are social, 2019). Internet of Things (IoT) juga tumbuh marak, sebagian besar perangkat terkoneksi dengan internet dan terdeteksi. Massifnya pertumbuhan digital di Indonesia memaksa kita semua untuk berubah menjadi digital mastery, terlebih pada situasi dan kondisi di tengah pandemi. Berbagai macam tantangan dan kesempatan ini berdampak pada masyarakat menjadi lebih lebih kritis dan sangat peduli akan berbagai macam haknya, baik hak politik, hak sosial, hak budaya, hak ekonomi, dan hak hukum yang meliputi tuntutan keadilan, kecepatan proses hukum, transparansi dan akuntabilitas penyelenggara hukum dan kepastian hukum.

Penyuluhan kemudian dilanjutkan dengan menekankan dampak dari membanjirnya data dan informasi akibat massifnya media digital; diantara dampaknya berupa kurangnya kontrol terhadap data dan informasi. Setiap orang dapat menjadi pemberita (citizen Journalism). Perang informasi di media digital dan merebaknya fake news atau hoax. Hal ini seperti yang dipaparkan penyuluh pada slidenya sebagai berikut:

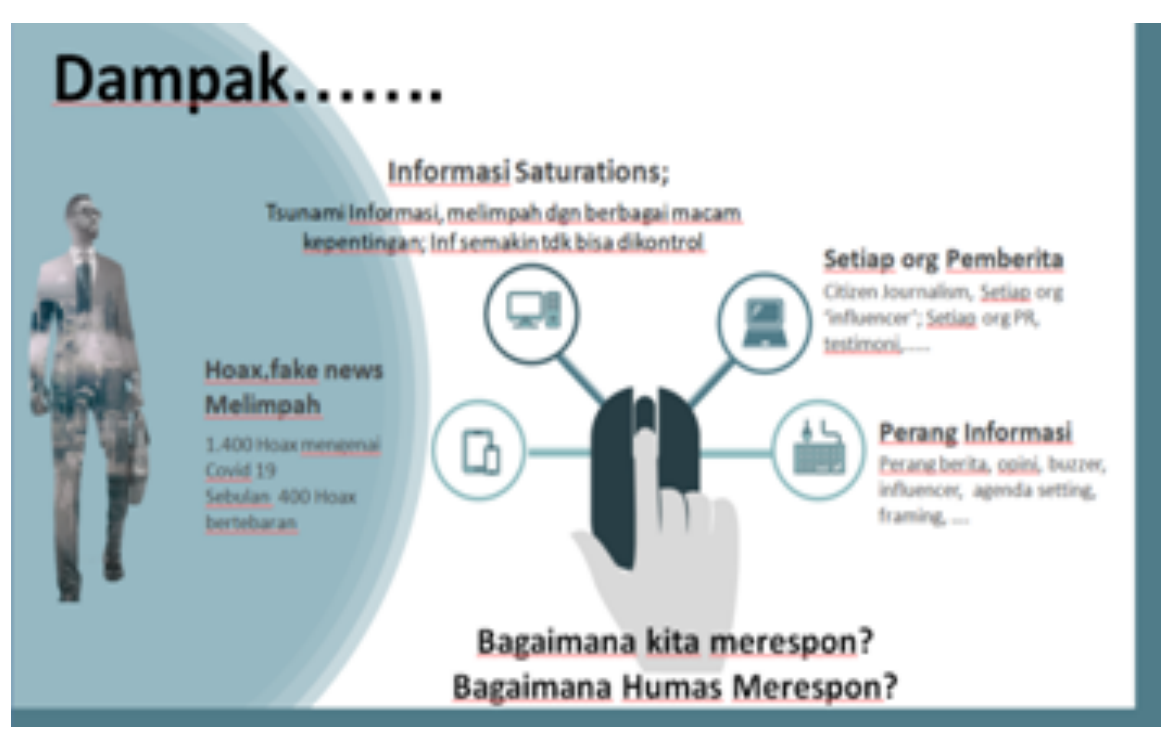

Gambar 2. Dampak Banjirnya Data dan Informasi

Dari berbagi macam dampak tersebut, maka yang jadi pertanyaan adalah bagaimana kita semua, khususnya para praktisi humas merespon dampak tersebut? Tentu untuk bisa mengontrol dan meminimalisir berbagai macam dampaknya tadi, diperlukan keterampilan berkomunikasi serta keterampilan kehumasan terkait dengan media relations. Penekanan pentingnya peran humas disebutkan oleh Bill Gates, CEO Microsoft yang menekankan bahwa 
jika ia mengalami kebangkrutan sampai hanya tersisa 1 dollar, maka 1 dollar tersebut akan diperuntukkan untuk kegiatan public relations (Gunning, 2020). Urgensi peran humas juga disampaikan oleh presiden RI, Bapak Joko Widodo yang mengisyaratkan mengenai pentingnya peran kehumasan ke depan, sebab pada dasarnya peran humas ialah mensosialisasikan pesan positif dan prestasi kepada publik agar terbangun kepercayaan dan reputasi Lembaga (Cawidu, 2016). Penyuluh juga menyadur arahan presiden Joko Widodo mengenai peran kehumasan, baik untuk kepentingan rakyat dan kepentingan global. Untuk kepentingan rakyat, humas harus dapat menyediakan dan mendistribusikan informasi dan data kepada rakyat dengan cepat, dan diperlukan koordinasi data dan informasi sehingga terbentuk narasi tunggal, perubahan paradigma kerja juga disinggung presiden Joko Widodo dengan meninggalkan cara kerja lama serta ditekankan perlu terbentuknya kepercayaan dari rakyat berkat kerja kehumasan, khususnya Government Public Relations (Cawidu, 2016).

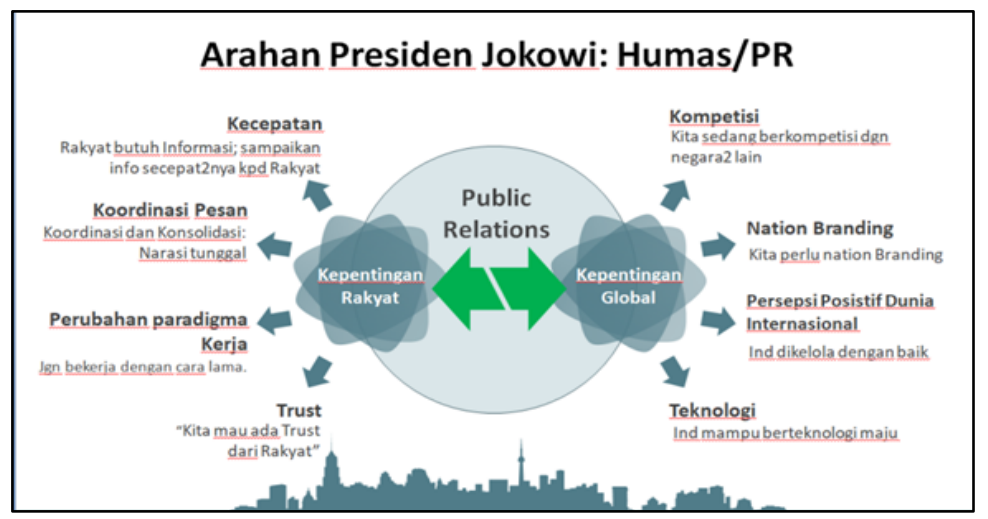

Gambar 3. Arahan Presiden Joko Widodo Mengenai Humas

Berdasarkan latar belakang, dampak dan arahan presiden; penyuluh memberikan alternatif solusi peningkatan peran kehumasan, di tengah kondisi dan situasi di berbagai macam kementerian atau lembaga pemerintah termasuk di lingkungan Mahkamah Agung. Kerap kali masalah sumber daya manusia berupa kurangnya tenaga humas selalu menjadi kendala dan alasan. Untuk itu diperlukan konsep everyone is public relations. Suatu konsep public relations yang mengharuskan semua orang dalam lembaga tersebut menjadi tenaga humas. Jadi tidak hanya yang berprofesi sebagai humas semata yang menjalankan aktivitas kehumasan, namun semua orang; mulai dari ketua Mahkamah Agung, para ketua pengadilan, para hakim dan seluruh stakeholder Mahkamah Agung harus dikerahkan dan ikut berkontribusi menjadi seorang humas. Paling tidak memiliki jiwa public relations, salah satunya tidak tabu atau tidak takut menghadapi media atau pers. Justru media atau pers ini dijadikan mitra strategis dalam menyampaikan berbagai macam agenda dan keberhasilan produk hukum di lingkungan Mahkamah Agung.

Kendala lain yang sering dikeluhkan oleh peserta adalah aspek etika penegak hukum, dengan argumen bahwa penegak hukum secara etika tidak dianjurkan untuk bersosialisasi terlalu dekat dengan masyarakat, termasuk dengan media atau pers. Dalam hal ini, tentu kegiatan 
berhubungan dengan media masih dapat dilakukan dengan baik selama tidak menganggu integritas dan jalannya proses hukum dengan cara bagaimana para hakim dapat mengidentifikasi dengan jeli berbagai maksud dan kepentingan dari para stakeholdernya termasuk dengan media atau pers. Hal ini tentu sejalan dengan pemikiran bahwa media mempunyai kekuatan dalam mempengaruhi opini publik dan menyampaikan berbagai macam nilai kepada masyarakat. Hal ini seperti yang diungkapkan oleh Ikhsano dan Jakarudi (2020) yang menyatakan bahwa ada berbagai bentuk media yang dapat digunakan untuk mengkampanyekan berbagai nilai yang ada kepada masyarakat. Media juga tidak bebas kepentingan, seperti diungkapkan Ikhsano (2020) bahwa pendekatan ekonomi politik media juga tidak hanya melihat peran media sebagai industri transnasional, tapi juga berbagai kepentingan yang diakomodasi media. Untuk itu sangat diperlukan kedekatan dengan media agar kita dapat memahami kepentingannya dan dapat mengakomodasi kepentinagan tersebut.

Selanjutnya materi penyuluhan membahas mengenai keterampilan manajemen media atau hubungan dengan media yang meliputi berbagai macam kegiatan; mulai dari bagaimana mengemas kegiatan press conference yang baik; menyiapkan press kit yang menarik terdiri dari press release yang memiliki nilai berita dan human interest yang baik, disertai dengan adanya infografis serta video dari press release tersebut. Di tengah peningkatan media digital saat ini, tentu video press release menjadi salah satu alternatif jitu dalam memenuhi dahaga informasi dan data para awak media. Terlebih ketika institutsi memiliki acara yang besar, sangat disayangkan jika tidak dipublikasikan karena bisa berdampak baik bagi citra maupun reputasi institusi. Seperti diungkapkan Harwinda \& Ikhsano (2020) yang menyatakan bahwa mengelola acara terbesar dapat menjadi contoh bagi publik guna mendapatkan hasil reputasi yang baik dan sesuai tujuan yang dicapai.

Media visit juga menjadi salah satu alat dalam kegiatan berhubungan dengan media. Dalam hal ini dapat dilakukan penjadwalan waktu tertentu untuk selalu mengunjungi berbagai media, baik itu media mainstream maupun media digital sehingga dapat menambah daftar media partner. Kunci utama keberhasilan hubungan dengan media adalah dengan begitu eratnya kita berhubungan dengan media partner, maka dapat menyeleksi berbagai macam pemberitaan mengenai institusi kita.

Dalam melakukan kunjungan media, sebenarnya tidak terlalu diperlukan suatu persiapan khusus atau bila hanya ada suatu nilai berita yang akan kita sampaikan; namun dapat dilakukan secara berkala guna terus menunjang hubungan baik dengan media. Media gathering juga dapat dijadikan salah satu agenda dalam berhubungan media. Sesekali para ketua pengadilan, para hakim dapat melakukan aktivitas bersama dengan awak media; baik itu olahraga Bersama, bersepeda, sepak bola, tenis dan lain sebagainya. CEO Interview juga salah satu bentuk dalam berhubungan dengan media. Pada kegiatan ini para Ketua 
pengadilan melakukan wawancara di berbagai media agar dapat menginformasikan kinerja dari pengadilan.

Di era sekarang ini, adanya influencer menjadi cara yang cukup ampuh untuk dapat mempengaruhi masyarakat. Influencer yang dimaksud tentu tidak harus selalu seorang artis atau selebgram yang mempunyai follower cukup banyak di berbagai macam media sosial, yang terpenting adalah yang memiliki daya pengaruh yang relatif kuat. Tetapi tidak dipungkiri bahwa popularitas dari seorang selebriti membuat pesan menjadi lebih mudah diingat, dapat diandalkan dan dapat dipercaya (Pinaria, Ikhsano \& Sutjipto, 2020). Namun demikian, influencer dapat diambil dari para akademisi, tokoh masyarakat dan juga para stakeholder lainnya. Berbagai macam media managament tools tersebut seperti tergambarkan pada slide yang dipaparkan pembicara pada gambar di bawah ini:

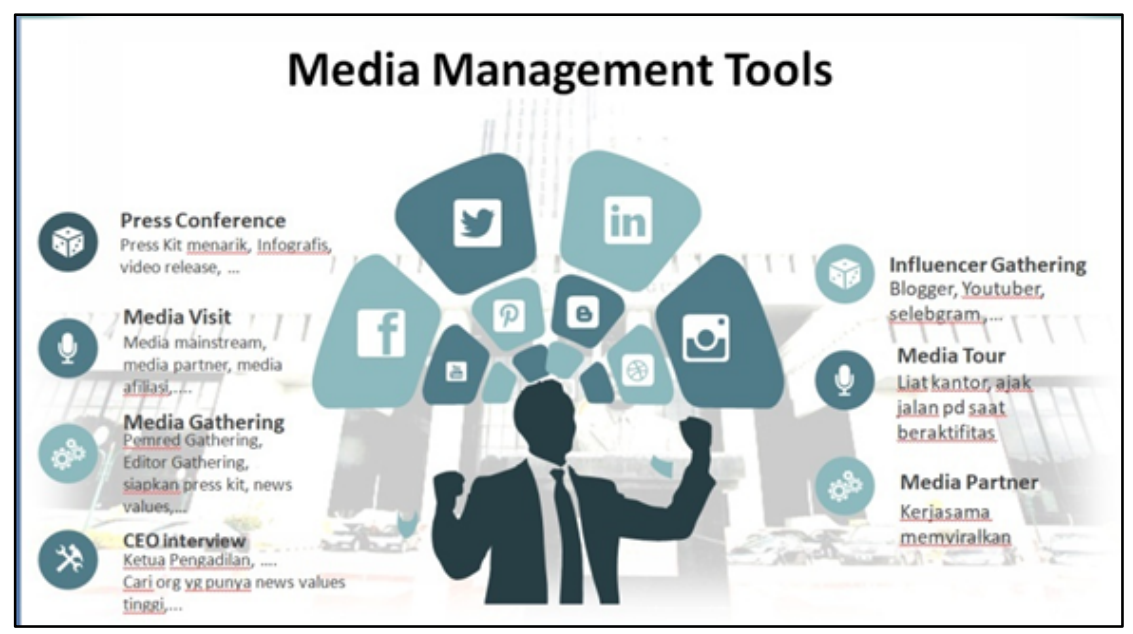

Gambar 4. Media Management Tools

Menjelang akhir penyuluhan, pembicara mengajak peserta yang sudah dibagi menjadi beberapa kelompok untuk melakukan pembahasan studi kasus manajemen media. Setiap kelompok yang terdiri dari 10 peserta didistribusikan studi kasus dan diminta untuk melakukan analisis serta menjabarkan keterampilan manajemen media seperti apa yang diperlukan. Berikut ini gambaran mengenai studi kasus yang diberikan:

Tabel 3: Mekanisme Studi Kasus Kelompok Peserta dan Solusi Media Management Tools yang ditawarkan Masing-Masing Kelompok

\begin{tabular}{|c|l|l|}
\hline Kelompok & \multicolumn{1}{|c|}{ Studi Kasus } & \multicolumn{1}{c|}{$\begin{array}{c}\text { Solusi } \\
\text { Management Tools }\end{array}$} \\
\hline I & $\begin{array}{l}\text { Pengadilan A mengalami kasus yang } \\
\text { menarik masyarakat adat, produk } \\
\text { hukum yang dihasilkan menyinggung } \\
\text { masyarakat adat dan mereka } \\
\text { melakukan demonstrasi besar-besaran }\end{array}$ & $\begin{array}{l}\text { Kelompok I menganalisis } \\
\text { bahwa perlu influencer atau } \\
\text { tokoh masyarakat dilibatkan } \\
\text { dan juga tokoh masyarakat } \\
\text { tersebut menjadi orang ketiga }\end{array}$ \\
\hline
\end{tabular}




\begin{tabular}{|c|c|c|}
\hline & $\begin{array}{l}\text { di pengadilan. Bagaimana } \\
\text { memanfaatkan media management } \\
\text { tools agar masalah dapat selesai dan } \\
\text { tidak berdampak pada citra pengadilan } \\
\text { A? }\end{array}$ & $\begin{array}{l}\text { ketika berbagai macam media } \\
\text { mencari data dan informasi }\end{array}$ \\
\hline II & $\begin{array}{l}\text { Pengadilan B mendapatkan banyak } \\
\text { pemberitaan negatif terkait produk } \\
\text { hukum berupa berkurangnya jumlah } \\
\text { waktu terpidana korupsi. Bagaimana } \\
\text { memanfaatkan media management } \\
\text { tools agar masalah dapat selesai dan } \\
\text { tidak berdampak pada citra pengadilan } \\
\text { B? }\end{array}$ & $\begin{array}{l}\text { Kelompok II menganalisis } \\
\text { bahwa media dapat menjadi } \\
\text { senjata ampuh dalam } \\
\text { membentuk opini publik. } \\
\text { Media management tools yang } \\
\text { dapat dilakukan adalah dengan } \\
\text { sesering mungkin } \\
\text { berhubungan dengan media } \\
\text { melalui media gathering } \\
\text { sambil menyisipkan pesan- } \\
\text { pesan yang disampaikan } \\
\text { kepada masyarakat }\end{array}$ \\
\hline III & $\begin{array}{l}\text { Pengadilan C mendapatkan kasus } \\
\text { sengketa pemilukada. Dua massa saling } \\
\text { menklaim kemenangan pemilukada dan } \\
\text { masing-masing kandidat menghubungi } \\
\text { para 'baking' nya berupa tokoh-tokoh } \\
\text { nasional, tokoh2 nasional tersebut } \\
\text { kerap menghubungi ketua pengadilan. } \\
\text { Apa yang menjadi dasar masalah dan } \\
\text { apa tindakan media management tools } \\
\text { terbaik yang dapat dilakukan? }\end{array}$ & $\begin{array}{l}\text { Kelompok III menganalisis } \\
\text { bahwa dasar masalahnya } \\
\text { adalah sengketa pemilukada, } \\
\text { untuk itu diperlukan data dan } \\
\text { infromasi yang trasparan dan } \\
\text { disampaikan secara terbuka } \\
\text { kepada kedua belah pihak, } \\
\text { sedangkan pressure politik dari } \\
\text { tokoh nasional dapat di atas } \\
\text { dengan media management } \\
\text { tools berupa press conference } \\
\text { menyampaikan data dan } \\
\text { infromasi yang terbuka }\end{array}$ \\
\hline IV & $\begin{array}{l}\text { Pengadilan D mengalami tekanan dari } \\
\text { kasus perceraian pasangan artis } \\
\text { ternama. Berbagai media/pers } \\
\text { berbondong-bondong mencari data dan } \\
\text { infromasi yang sensasional. Para awak } \\
\text { media memaksa untuk melakukan } \\
\text { wawancara kepada kedua artis yang } \\
\text { sedang bermasalah. Bagaimana } \\
\text { pengadilan dapat memanfaatkan } \\
\text { moment ini dan menghandle hal ini } \\
\text { melalui media management tools? }\end{array}$ & $\begin{array}{l}\text { Kelompok IV menyarankan } \\
\text { bahwa Hubungan Masyarakat } \\
\text { pengadilan harus mempunyai } \\
\text { media center sendiri sehingga } \\
\text { semua data dan informasi } \\
\text { yang dibutuhkan oleh awak } \\
\text { media dapat dikontrol dan } \\
\text { keluar dari satu pintu. Setiap } \\
\text { pemberitaan mengenai kasus } \\
\text { artis tersebut selalu diselipkan }\end{array}$ \\
\hline
\end{tabular}




\begin{tabular}{|c|c|c|}
\hline & & $\begin{array}{l}\text { dengan berbagai macam } \\
\text { prestasi dari pengadilan. }\end{array}$ \\
\hline $\mathbf{V}$ & $\begin{array}{l}\text { Pengadilan E mendapatkan suatu } \\
\text { penghargaan tertinggi sebagai salah } \\
\text { satu pengadilan terbaik di Indonesia, } \\
\text { namun tidak ada satu mediapun yang } \\
\text { meliput. Apa yang dilakukan oleh } \\
\text { pengadilan agar mendapatkan banyak } \\
\text { liputan pencapaian tersebut? }\end{array}$ & $\begin{array}{l}\text { Kelompok } \mathrm{V} \text { menyarankan } \\
\text { bahwa penyebaran pers } \\
\text { release kepada para media } \\
\text { dibarengi dengan mengandeng } \\
\text { para influencer agar prestasi } \\
\text { pengadilan tersebut dapat } \\
\text { terberitakan dengan baik }\end{array}$ \\
\hline VI & $\begin{array}{l}\text { Pengadilan C mendapatkan kasus } \\
\text { sengketa pilkada. Dua massa saling } \\
\text { menklaim kemenangan pemilukada dan } \\
\text { masing-masing kandidat menghubungi } \\
\text { para 'baking' nya berupa tokoh-tokoh } \\
\text { nasional, tokoh2 nasional tersebut } \\
\text { kerap menghubungi ketua pengadilan. } \\
\text { Apa yang menjadi dasar masalah dan } \\
\text { apa tindakan media management tools } \\
\text { terbaik yang dapat dilakukan? }\end{array}$ & $\begin{array}{l}\text { Kelompok VI menganalisis } \\
\text { bahwa dasar masalahnya } \\
\text { adalah kepentingan para tokoh } \\
\text { nasional yang ikut campur } \\
\text { masalah daerah, Untuk itu } \\
\text { diperlukan lobi dan negosiasi } \\
\text { dari Mahkamah agung melalui } \\
\text { kementrian Hukum dan HAM } \\
\text { agar memastikan tidak ada } \\
\text { intervensi hukum. }\end{array}$ \\
\hline VII & $\begin{array}{l}\text { Pengadilan A mengalami kasus yang } \\
\text { menarik. masyarakat adat, produk } \\
\text { hukum yang dihasilkan menyinggung } \\
\text { masyarakat adat dan mereka } \\
\text { melakukan demonstrasi besar-besaran } \\
\text { di pengadilan. Bagaimana } \\
\text { memanfaatkan media management } \\
\text { tools agar masalah dapat selesai dan } \\
\text { tidak berdampak pada citra pengadilan } \\
\text { A? }\end{array}$ & $\begin{array}{l}\text { Kelompok VII memberikan } \\
\text { analisis bahwa perlu adanya } \\
\text { literasi hukum pada para } \\
\text { masyarakat adat agar tidak } \\
\text { terjadi lagi, kegiatan literasi } \\
\text { hukum ini mengandeng media } \\
\text { partner. }\end{array}$ \\
\hline VIII & $\begin{array}{l}\text { Pengadilan B mendapatkan banyak } \\
\text { pemberitaan negatif terkait produk } \\
\text { hukum berupa berkurangnya jumlah } \\
\text { waktu terpidana korupsi. Bagaimana } \\
\text { memanfaatkan media management } \\
\text { tools agar masalah dapat selesai dan } \\
\text { tidak berdampak pada citra pengadilan } \\
\text { B? }\end{array}$ & $\begin{array}{l}\text { Kelompok VIII memberikan } \\
\text { analisis bahwa pengurangan } \\
\text { 'diskon' hukuman koruptor } \\
\text { sudah berdasarkan undang- } \\
\text { undang yang berlaku dan tidak } \\
\text { menyalahi aturan, media } \\
\text { management tools yang dapat } \\
\text { dilakukan adalah dengan } \\
\text { pemred gartehring untuk } \\
\text { dapat menyamakan persepsi } \\
\text { masalah hukum sehingga para } \\
\text { Pimpinan redaksi mengerti }\end{array}$ \\
\hline
\end{tabular}




\begin{tabular}{|c|c|c|}
\hline & & $\begin{array}{l}\text { dengan jelas sambil meberikan } \\
\text { data dan informasi mengenai } \\
\text { berbagai macam hukuman } \\
\text { yang 'berat' pada koruptor lain } \\
\text { sebagai penyeimbang data dan } \\
\text { informasi. }\end{array}$ \\
\hline IX & $\begin{array}{l}\text { Pengadilan D mengalami tekanan dari } \\
\text { kasus perceraian pasangan artis } \\
\text { ternama. Berbagai media/pers } \\
\text { berbondong-bondong mencari data dan } \\
\text { informasi yang sensasional. Para awak } \\
\text { media memaksa untuk melakukan } \\
\text { wawancara kepada kedua artis yang } \\
\text { sedang bermasalah. Bagaimana } \\
\text { pengadilan dapat memanfaatkan } \\
\text { moment ini dan menangani hal ini } \\
\text { melalui media management tools? }\end{array}$ & $\begin{array}{l}\text { Kelompok IX menyarankan } \\
\text { bahwa hubungan masyarakat } \\
\text { pengadilan harus } \\
\text { memanfaatkan moment ini } \\
\text { dengan cara menjadikan } \\
\text { semua latar belakang } \\
\text { interview artis dengan latar } \\
\text { belakang pengadilan dan } \\
\text { cuplikan-cuplikan dari ketua } \\
\text { pengadilan sehingga nama } \\
\text { pengadilan dapat terangkat }\end{array}$ \\
\hline$x$ & $\begin{array}{l}\text { Pengadilan E mendapatkan suatu } \\
\text { penghargaan tertinggi sebagai salah } \\
\text { satu pengadilan terbaik di Indonesia, } \\
\text { namun tidak ada satu mediapun yang } \\
\text { meliput. Apa yang dilakukan oleh } \\
\text { pengadilan agar mendapatkan banyak } \\
\text { liputan pencapaian tersebut? }\end{array}$ & $\begin{array}{l}\text { Kelompok X menyarankan } \\
\text { bahwa perlu adanya press } \\
\text { conference, media gathering } \\
\text { dan juga pernyataan dan } \\
\text { ucapaan dari para tokoh agar } \\
\text { menjadi magnet bagi media. }\end{array}$ \\
\hline
\end{tabular}

Dari kegiatan studi kasus tersebut, maka setelah dilakukan evaluasi dengan mengedepankan pemahaman akan pentingnya peran kehumasan dan pentingnya media management tools maka dapat disimpulkan bahwa:

Tabel 4: Penilaian Studi Kasus

\begin{tabular}{|c|c|c|c|}
\hline \multirow{2}{*}{ Kelompok } & \multicolumn{3}{|c|}{ Aspek Penilaian } \\
\cline { 2 - 4 } & $\begin{array}{c}\text { Ketepatan } \\
\text { Identifikasi Masalah }\end{array}$ & $\begin{array}{c}\text { Pemahaman Public } \\
\text { Relations }\end{array}$ & $\begin{array}{c}\text { Keterampilan Media } \\
\text { Management Tools }\end{array}$ \\
\hline I & Baik & Baik & Sangat Baik \\
\hline II & Baik & Cukup Baik & Baik \\
\hline III & Baik & Baik & Sangat Baik \\
\hline IV & Cukup Baik & Cukup Baik & Baik \\
\hline V & Sangat Baik & Baik & Baik \\
\hline VI & Sangat Baik & Baik & Sangat Baik \\
\hline VII & Baik & Baik & Sangat Baik \\
\hline
\end{tabular}




\begin{tabular}{|c|c|c|c|}
\hline VIII & Sangat Baik & Baik & Sangat Baik \\
\hline IX & Sangat Baik & Sangat Baik & Sangat Baik \\
\hline X & Cukup Baik & Cukup Baik & Baik \\
\hline
\end{tabular}

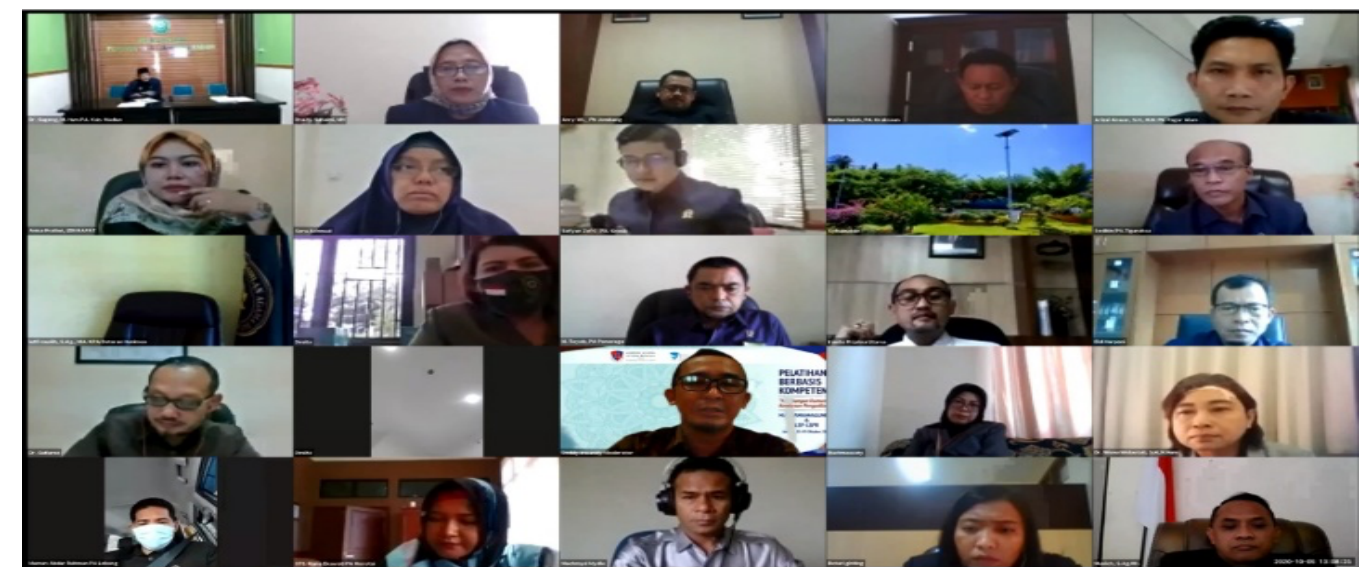

Gambar 5. Peserta Pelatihan

Dari hasi penilaian studi kasus tersebut, dapat dikatakan bahwa secara umum aspek identifikasi masalah berada pada kategori baik, aspek pemahaman public relations berada pada kategori baik sedangkan aspek keterampilan media management tools berada pada kategori sangat baik. Hal ini dapat dikatakan bahwa penyuluhan ini berjalan dengan baik dan menghasilkan suatu luaran yang diharapkan. Pada akhir penyuluhan, peserta juga diberikan kesempatan bertanya, berdiskusi dengan pembicara/penyuluh, waktu yang diberikan oleh panitia sebesar 15 menit. Peserta yang antusias bertanya sebanyak 18 peserta sehingga waktu yang telah ditentukan ditambah 15 menit untuk mengakomodasi pertanyaan peserta.

\section{SIMPULAN DAN SARAN}

Kegiatan pengabdian kepada masyarakat ini dapat disimpulkan memenuhi tujuan, yaitu pengembangan pemahaman public relations dan keterampilan media management tools para peserta, yaitu para ketua pengadilan, para hakim dan para Humas di lingkungan Mahkamah Agung. Dari 100 peserta dapat juga disimpulkan materi yang disampaikan berguna dan bermanfaat dan dapat diaplikasikan pada aktivitas sehari-hari para peserta. Kegiatan pengabdian semacam ini dapat dilakukan kembali dikemudian hari dengan peserta yang berbeda di lingkungan Mahkamah Agung yang belum mendapatkan kesempatan atau dilakukan pada peserta yang sama dengan materi penyuluhan yang lebih menekankan pada pengetahuan lebih detail mengenai community relations, agenda setting dan public speaking sehingga akan sangat membantu pemahaman dan keterampilan yang sudah didapatkan pada pengabdian kepada masyarakat ini. Terlebih dimasa pandemi ini, tentu banyak kegiatan dilakukan di rumah sehingga dapat menambah aktivitas yang bermanfaat dan produktif di 
rumah. Serta dari aspek budget, kegiatan yang diadakan virtual seperti ini dapat menghemat budget penyelenggaraan dibanding dengan kegiatan penyuluhan secara luring dengan mendatangkan peserta dari berbagai daerah di Indonesia.

\section{UCAPAN TERIMA KASIH}

Kegiatan penyuluhan ini dapat terselenggara berkat kerjasama Institut Komunikasi dan Bisnis LSPR dan Pusdiklat Mahkamah Agung, sehingga penulis patut menyampaikan penghargaan dan juga ucapan terima kasih kepada Mahkamah Agung yang telah mempercayakan kegiatan ini kepada Institut Komunikasi dan Bisnis LSPR melalui Lembaga Sertifikasi Profesi-LSPR. Ucapan terima juga disampaikan kepada Lembaga Serfitikasi Profesi-LSPR yang telah mempercayakan penulis sebagai penyuluh dalam kegiatan pengabdian kepada masyarakat ini.

\section{REFERENSI}

Breakendriedge, D. (2008). PR.2.0 New Media, New Tools, New Audiences. New Jersey: Pearson Education Inc Publishing.

Cawidu, I. (2016, April 14). Government Public Relations (GPR). Diakses dari https://slideplayer.info/slide/11862888/

Gunning, E. (2020, February 24). "If I Was Down to My Last Dollar, I'd Spend It on Public Relations"Bill Gates. Diakses dari https://irishacademy.ie/if-i-was-down-to-my-lastdollar-id-spend-it-on-public-relations-bill-gates/

Harwinda, A. \& Ikhsano, A. (2020). Pengaruh Special Event Pembukaan ASIAN GAMES ke-18 Tahun 2018 terhadap Reputasi Ketua Panitia INASGOC. Jurnal Komunikasi.14 (1). 3142. https://doi.org/10.21107/ilkom.v14i1.6029

Ikhsano, A., \& Jakarudi, J. (2020). Representation of Black Feminism in Hidden Figures. Nyimak Journal of Communciation. Vol. 4 No. $2 . \quad$ 169-180. http://dx.doi.org/10.31000/nyimak.v4i2.2358

Ikhsano, A. (2020). Melawan Hegemoni Perfilman Hollywood. Tangerang: Indigo Media.

Iprahumas Indonesia. (2020). The Real GPR: 111 Tulisan Pranata Humas Indonesia. Jakarta: Ikatan Pranata Humas Indonesia.

Kementerian Komunikasi dan Informatika Republik Indonesia. (2016). Lingkup Program Government

Public

Relations.

Diakses

dari 
https://www.kominfo.go.id/content/detail/6857/lingkup-program-governmentpublic-relations/0/pp_gpr

Pinaria, J.M \& Ikhsano, A., etc. (2020). Accelerating Diffusion Innovation Using Celebrities as Opinion Leaders for Millennials: HPV Vaccines in Indonesia, Jurnal Komunikasi; Malaysian Journal of Communication. Vol. 36 No. 3. 32-48. https://doi.org/10.17576/JKMJC-2020-3603-03.

We are Social. (2019). Digital 2019: Essential Insights Into How People Around The World Use The Internet, Mobile Devices, Social Media, and E-Commerce [PDF File]. Retrieved from https://wearesocial.com/global-digital-report-2019

Widowati, D. (2019). Peran Corporate Communication PT Krakatau Steel dalam Mengatasi Krisis. Communicare: Journal of Communication Studies. 6(2). 190-203. https://doi.org/10.37535/101006220196 